\title{
CAR-T-Cell Therapy: Present Progress and Future strategies
}

\author{
Muddasir Hassan Abbasi ${ }^{1, *(}$, Amna Riaz ${ }^{1}$, Muhammad Babar Khawar ${ }^{2}{ }^{*}$, Adil Farooq $^{1}$, Ayesha Majid ${ }^{1}$, \\ Nadeem Sheikh ${ }^{3, *(1)}$
}

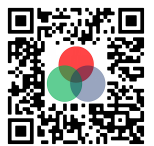

Use your smartphone to scan this QR code and download this article

${ }^{I}$ Department of Zoology, University of Okara, Punjab, Pakistan

${ }^{2}$ Applied Molecular Biology and Biomedicine Lab, Department of Zoology, University of Narowal, Narowal, Pakistan

${ }^{3}$ Cell \& Molecular Biology Lab, Institute of Zoology, University of the Punjab, Lahore, Pakistan

\section{Correspondence}

Muddasir Hassan Abbasi, Department of Zoology, University of Okara, Punjab, Pakistan

Email: dr.muddasi@@uo.edu.pk

\section{Correspondence}

Muhammad Babar Khawar, Applied Molecular Biology and Biomedicine Lab, Department of Zoology, University of Narowal, Narowal, Pakistan

Email: babarkhawar@yahoo.com

\section{Correspondence}

Nadeem Sheikh, Cell \& Molecular Biology Lab, Institute of Zoology, University of the Punjab, Lahore, Pakistan

Email: Nadeem.zool@pu.edu.pk

History

- Received: Jan 08, 2022

- Accepted: Feb 25, 2022

- Published: Feb 28, 2022

DOI : 10.15419/bmrat.v9i2.726

\section{Check for updates}

\section{Copyright}

(-) Biomedpress. This is an openaccess article distributed under the terms of the Creative Commons Attribution 4.0 International license.

\begin{abstract}
Chimeric antigen receptor (CAR) T-cell therapy is a type of immunotherapy that uses the patient's immune system. It creates cancer-killing T cells through genetic modification that targets tumor antigens. CAR consists of three fundamental units, the extracellular, transmembrane, and intracellular domains. CARs are rapidly evolving with progress in the field of immunotherapy starting from first-generation CARs to next-generation CARs. Different cancer types, including B-cell malignancies, are being treated by CAR-T therapy. The FDA has approved two CAR-T therapies, namely, tisagenlecleucel and axicabtagene ciloleucel. The recently approved CAR-T products are Lisocabtagene maraleucel and Idecabtagene vicleucel. Despite the success of CAR-T therapy, several limitations, including cytokine release syndrome and neurotoxicity, need to be overcome. In the present review, we have provided an overview of CAR generations, their applications, potential limitations, and possible solutions for improving CAR-T therapy for a variety of tumor types.
\end{abstract}

Key words: CAR-T, Immunotherapy, Malignancies, T-cell receptor, Tumor antigens

\section{INTRODUCTION}

Cancer is one of the major causes of death worldwide. T cells, a type of white blood cell (WBC), are known to kill cancer cells. Chimeric antigen receptors (CARs) are WBCs specialized in targeting cancer cells by binding to their surface proteins. CAR-T-cell therapy harnesses the power of these $\mathrm{T}$ cells and CARs to kill cancer cells effectively. CAR-T cells are called the first living drugs, as once they are activated and infused, they remain in the body and show long-term results ${ }^{1}$. CAR-T-cell therapy mostly uses autologous $\mathrm{T}$ cells in which the patient's own T cells are drawn out followed by genetic modifications and insertion into the same patient.

The FDA has approved a number of CAR-T therapies for patients with different types of cancers. Mainly two trademarks are registered: kymriah ${ }^{\mathrm{TM}}$ (tisagenlecleucel) and yescarta ${ }^{\mathrm{TM}}$ (axicabtagene ciloleucel). Recently, approved CAR-T therapy agents include lisocabtagene maraleucel (breyanzi ${ }^{\mathrm{TM}}$ ) and idecabtagene vicleucel (abecma ${ }^{\mathrm{TM}}$ ). Various antigens have been explored as potential targets for T-cell therapies in hematological and solid tumors. For instance, CD19 is used for B-cell acute lymphoblastic leukemia (B$\mathrm{ALL})^{2}$ and chronic lymphocytic leukemia (CLL). The majority of patients with relapsed or refractory B-ALL (R/R B-ALL) and CD19-targeted CAR-T cells have achieved complete disease remission ${ }^{3}$. Several toxicities are associated with the application of CAR-Tcell therapy, such as cytokine release syndrome (CRS), neurological toxicities, B-cell aplasia and hypogammaglobinemia. The two effective ways to cope with CRS and neurologic toxicity are to use tocilizumab and corticosteroids effectively.

This mini review highlights the recent developments in CAR-T therapy, its effective application in combating various types of cancers, updated information about the latest clinical trials and highlights its possible limitations.

\section{CANCER IMMUNOTHERAPY AND ADOPTIVE CELL THERAPY}

Immunotherapy is a treatment that makes use of the body's natural immune system, boosts its activity, and efficiently combats cancer and other disorders ${ }^{4}$. Immunotherapy helps in the direct control of killing cancerous cells by making the cells visible to the cancer fighting cells of the body ${ }^{5}$. Immunotherapy has successfully evolved in recent decades to address therapeutic barriers, bringing innovation to cancer treatment.

Active and passive immunotherapies are the two practiced immunotherapies. The former includes tumor vaccines and later includes monoclonal antibodies, oncolytic virotherapy and adoptive T-cell therapy (ACT). ACT is a type of passive immunotherapy that utilizes the body's own T cells to treat cancer by manipulation of $\mathrm{T}$ cells outside the body, followed by their expansion and finally modified T-cell infusion 
back into the body ${ }^{6}$. The work was initiated in the 1980s when a new method was introduced to produce a large number of autologous lymphoid cells to fight cancer cells by Rosenberg's team ${ }^{7}$.

\section{CHIMERIC ANTIGEN RECEPTOR (CAR) AND CAR-T-CELL THERAPY}

CARs are fusion proteins specifically manipulated to target antigens expressed on the surface of cells. In 1989, at the Weizmann Institute of Science, Eshhar's group developed the first chimeric receptor ${ }^{8}$. In a very brief time span after their development and application, CAR-T cells have undergone an evolution of generations. CAR is a modified receptor consisting of three essential domains, including extracellular, transmembrane and intracellular domains 9,10 . The intracellular domain helps in signaling $\mathrm{T}$ cells that allows the killing of cancerous cells in a human leukocyte antigen (HLA)-independent manner ${ }^{11,12}$.

CAR-T therapy has revolutionized the field of treating various cancers. It is a way of providing personalized treatment according to the disease type and body requirements. It includes genetically modifying a person's own T cells that will later own bind to the tumor antigen. This process is followed by proliferation and infusion back to the body to target and kill cancerous cells $^{13}$.

\section{GENERALIZED STRUCTURAL DESIGN OF CHIMERIC ANTIGEN RECEPTORS}

Fundamentally, CAR consists of three main domains: the extracellular domain, transmembrane domain and intracellular domain ${ }^{\mathbf{1 , 1 4}}$. The extracellular domain is composed of a single-chain variable fragment $(\mathrm{scFv})$ that is a fusion protein of the variable region of the light and heavy chains of the antibody. It is joined with the help of a spacer to the transmembrane domain that finally joins with the intracellular signaling domain, resulting in cytolysis of cancer cells $\mathbf{1 , 1 5 , 1 6}$. The extracellular scFv aids CAR-T cells in binding to the targeted cells, whereas the intracellular domain helps activate $\mathrm{T}$ cells ${ }^{17,18}$.

\section{GENERATION OF CHIMERIC ANTIGEN RECEPTORS}

To date, there have been five main generations of $\mathrm{CAR}^{19}$. The difference in each generation CAR mainly lies in the structure and functionality of the intracellular domain ${ }^{20}$. Figure 1 summarizes the major differences and similarities among various CAR generations.
First-generation CARs are capable of activation only. Second-generation CARs perform dual signaling, and third-generation CARs are capable of multiple signaling ${ }^{1}$. Significant limitations have been noted for first-generation CARs, with less T-cell proliferation and inadequate release of cytokines ${ }^{21}$. The second and third generation have an additional structural modification, the intracellular costimulatory domains $(\mathrm{CM})^{17}$. The $\mathrm{CM}$ in second-generation CARs may be $4-1 \mathrm{BB}^{22}$ or $\mathrm{CD} 28^{23,24}$. These modifications enhance the persistence and expansion of T cells. To further increase T-cell expansion and persistence, thirdgeneration CARs were added to both CD28 and 4$1 \mathrm{BB}$ with no change in extracellular and transmembrane domain structures ${ }^{25,26}$. TRUCK, the fourthgeneration CAR, stands for Tcells redirected for universal cytokine-mediated killing ${ }^{20}$. This generation has resulted in a huge modification in the intracellular domain of the $2^{\text {nd }}$ generation, i.e., the addition of cytokines such as interleukin 12 (IL-12), which activates natural killer (NK) cells in addition to other Tcells at the tumor site. IL-12 has the ability to cytolyse cancer cells that are not detected by CAR-T cells directly hence, IL-12 results in killing these cells by activating the innate immune response ${ }^{27}$. The fifth generation of CAR has anadditional modification of the binding site in the intracellular domain for the signal transducer and activator of transcription-3 (STAT3) transcription factor and another binding site for the interleukin-2 (IL-2) receptor ${ }^{28}$. Both these modifications provide better T-cell activation, persistence and proliferation by cytokine-inducing Janus kinase (JAK-STAT3/5) signaling ${ }^{29}$. The basic difference in each generation is shown in Figure 2.

\section{CAR-T THERAPY PROCEDURE}

Leukapheresis is the first step to initiate CAR-T therapy. In this procedure, the patient goes to an apheresis machine that is used in autologous T-cell collection $^{6}$. The patient's own blood is drawn out, white blood cells are separated from the peripheral blood into a bag, and then they are cryopreserved so they can be sent for further manufacturing. If enough $\mathrm{T}$ cells were not collected, the process of leukapheresis was repeated the next day (Figure 3).

Upon successful collection of WBCs, the cells are selected based on the genetic code for the chimeric antigen receptor employing viral transduction. For example, $\mathrm{T}$ cells are genetically transduced ex vivo with a lentiviral vector encoding the anti-CD19 CAR ${ }^{30}$. The cells that express their chimeric antigen on their surface are then expanded to form many copies followed by cryopreservation and sent back to the treatment site. Simultaneously. Before introducing the 


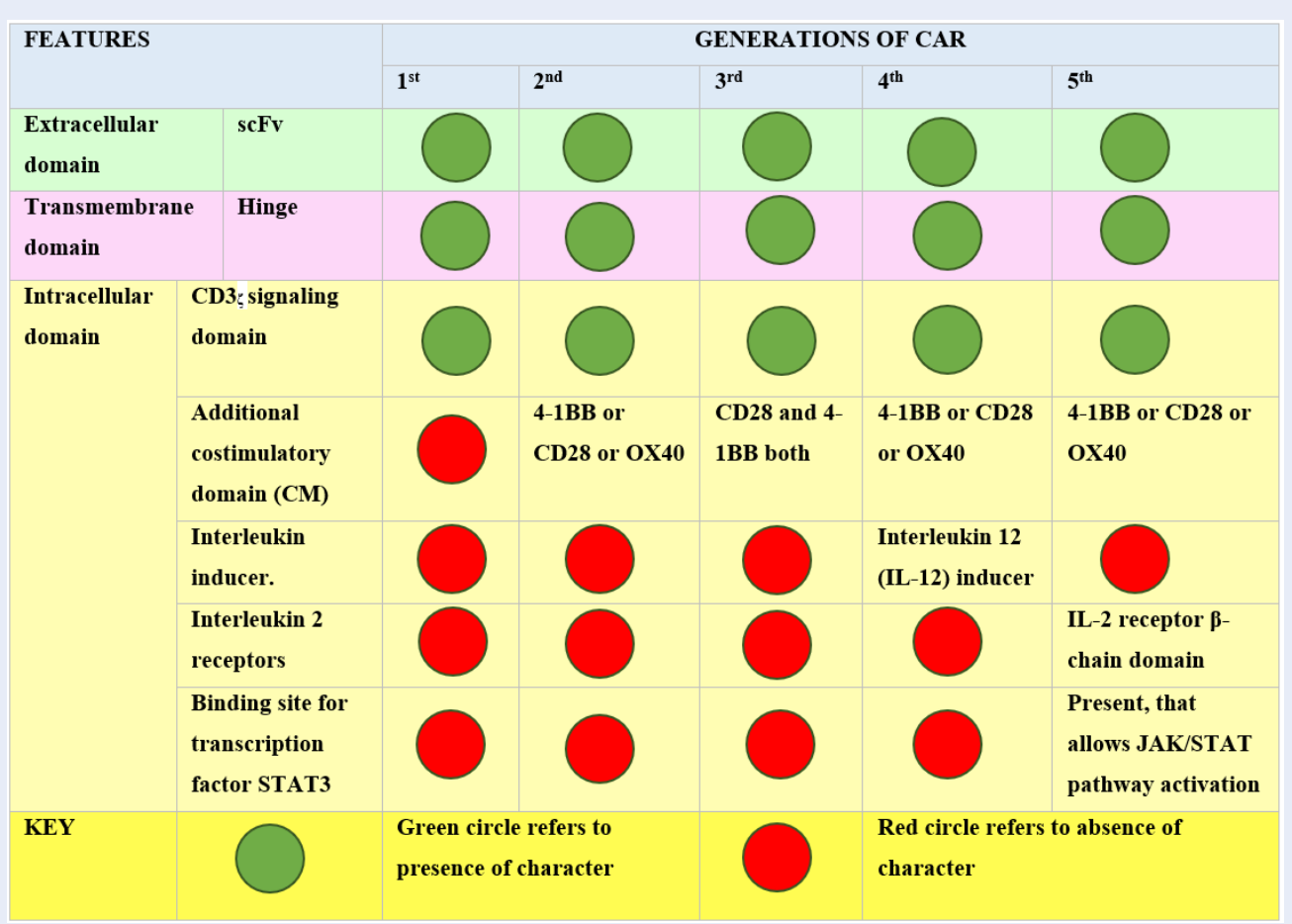

Figure 1: Significant differences between CAR-T-cell generations.

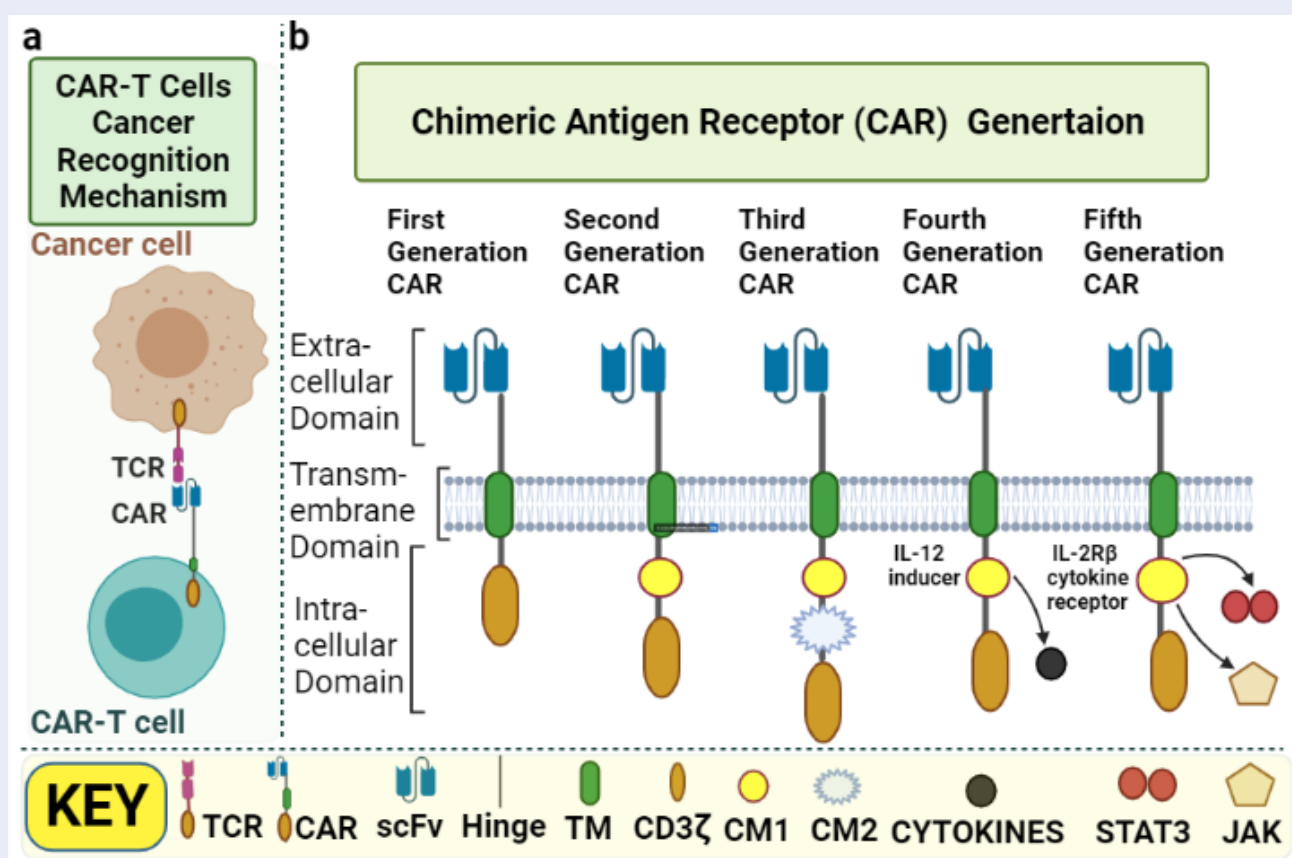

Figure 2: Structural details of CAR-T therapy. a) Recognition mechanism of cancer cells by CAR-T cells. b) Generations of Chimeric Antigen Receptor (CAR). A detailed description and abbreviations are given in the text. 


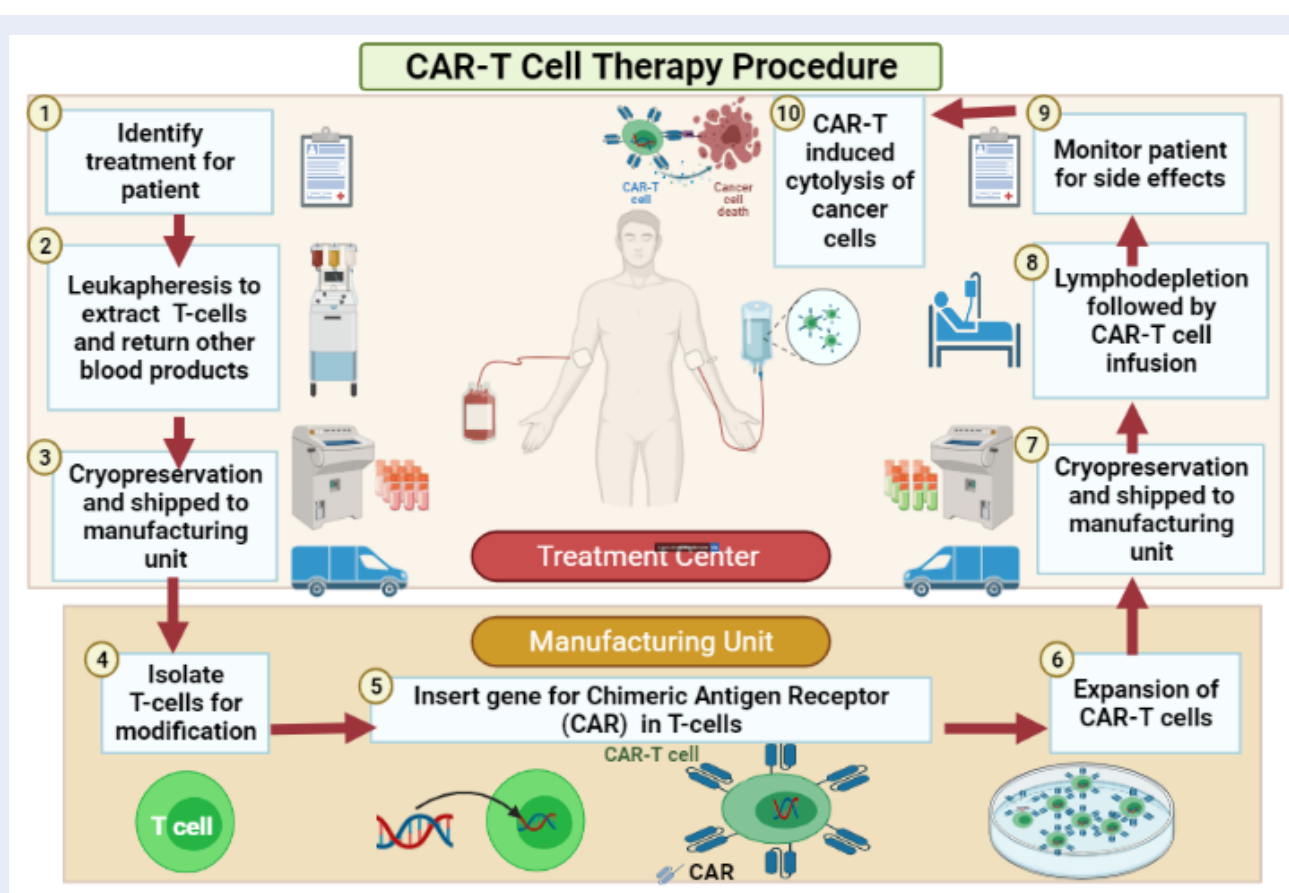

Figure 3: Stepwise procedure from collection of cells to proliferation until infusion, employed in CAR-T-cell therapy (1-10).

CAR-T cells, the patient was given chemotherapy in the form of lymphodepleting treatment for three days, such as fludarabine or cyclophosphamide, to clear the immune system to make space for newly manufactured CAR-T cells ${ }^{31}$.

Finally, the CAR-T cells are infused into the patients' blood. Inside the body, CAR-T cells target their cancer cells, expand rapidly and kill those cancer cells along with other B cells. The cytokines released by the destroyed cancer cells further lead to CAR-T-cell cell expansion $^{32}$.

An effective response rate in various R/R B-cell malignancies is shown in patients who undergo leukopheresis followed by preparative lymphodepletion and finally treated with autologous T-cell infusion engineered for the expression of CD19-targeted CAR-T cells ${ }^{33-36}$. The figure below shows the overall process of CAR-T therapy.

\section{CAR-T THERAPY CLINICAL APPLICATION}

In recent years, various experiments and trials in clinical setup have been performed to check the efficiency of various CAR-T therapy agents for targeting different antigen receptors. Targeting CD19 has shown outstanding results in treating patients with CLL, B-ALL,
Hodgkin lymphoma (HL) and B-NHL ${ }^{37,38}$. The first efficient result was shown for CLL, but later, it showed a lower response rate, whereas in the case of R/R ALL, it showed a ninety percent remission rate ${ }^{39}$. With patients suffering from B-ALL, using CAR-T cells that target CD19 resulted in complete remission rates of seventy to ninety-four percent ${ }^{37}$. After gaining efficient results, CAR-T therapy targeting CD19 is also used for patients suffering from FL and other kinds of B-cell-associated malignancies ${ }^{40}$. Other than targeting CD19, some studies have also shown efficient treatment by targeting $\mathrm{CD} 20^{41}$ and $\mathrm{CD} 30^{42}$. Recent advancements in CAR-T therapy have led to its effective use in treating solid tumors in addition to Bcell malignancies. It has been used for pediatric brain tumors that have caused fatalities in both adults and children. However, there are still some limitations to its effective use ${ }^{19}$.

\section{CAR-T THERAPY APPROVED AGENTS}

Currently, various CAR-T therapy agents are in use and approved by different drug regulatory agencies, such as the United States Food and Drug Administration (US FDA) and European Medicines Agency ${ }^{32}$. The four main approved agents are given below. 
Tisagenlecleucel by Kymriah ${ }^{\mathrm{TM}}$ is the first FDA approved CAR-T therapy ${ }^{43}$. It is used in patients suffering from R/R-ALL in both children and adults of approximately 3 years to 25 years of age ${ }^{44}$. On May 1 , 2018, it was approved for use in adult patients suffering from B-cell lymphomas. Currently, tisagenlecleucel is also reviewed by the FDA for its use in CLL, R/R B-cell-ALL, R/R diffuse large B-cell lymphoma (DL$\mathrm{BCL}$ ) and second-line DLBCL ${ }^{45}$. Despite its efficacy, this therapy comes with a high cost of nearly 475,000 dollars ${ }^{43}$.

Axicabtagene ciloleucel by Yescarta ${ }^{\mathrm{TM}}$ is another Tcell therapy agent that was approved by the FDA on October 18, 2017. It is prescribed therapy for patients suffering from DLBCL and R/R aggressive B-cell nonHodgkin lymphoma (B-NHL) ${ }^{6}$. Currently, this therapy is also being applied and tested for mantle cell lymphoma (MCL) and follicular lymphoma (FL) ${ }^{45}$. It's also an expensive therapy like tisagenlecleucel but its cost is little less, i.e., approximately $373,000 \mathrm{dol}-$ lars ${ }^{43}$.

Lisocabtagene maraleucel by Breyanzi ${ }^{\mathrm{TM}}$ is the third CAR agent approved on February 5, 2021 by the FDA. It is approved for treating adult patients suffering from R/R B-ALL lymphomas. Quite recently, in March 2021, another FDA approved CAR-T therapy; Idecabtagene vicleucel by Abecma ${ }^{\mathrm{TM}}$ was used for treating patients suffering from R/R $M M^{46,47}$. Even though they are approved, therapies are still a topic of research and experiments for studying their effectiveness and any associated resulting toxicity ${ }^{45}$.

\section{CAR-T THERAPY-ASSOCIATED TOXICITY}

With the outstanding results of CAR-T therapy, one may come across some toxic side effects induced by CAR-T-cell infusion. From mild to severe, some toxicities may be life-threatening or even fatal in some situations. The most common postprocedure toxicities for CAR-T-cell therapy include cytokine release syndrome (CRS) and neurological toxicities. The major CRS manifestations include fever, hypoxia, hypotension, cytopenia and fatigue ${ }^{48}$. CAR-T cells targeting CD19 may also damage B cells in addition to cancerous cells because CD19 is also found on the surface of normal B cells along with cancerous cells. In such cases, the patient may develop B-cell aplasia and hypogammaglobulinemia. There are multiple factors that affect the efficacy of CAR-T-cell therapy and induce posttreatment toxicity, including a high CAR-T-cell count in blood, peak cytokine levels and patient vulnerability to the immune system due to preparative chemotherapy ${ }^{48}$. The more common CRS-associated toxicity is usually treated with tocilizumab, which works on high interleukin-6 (IL6) levels ${ }^{49}$. If tocilizumab shows ineffective treatment for CRs, corticosteroids may be given to the patient. Normally, corticosteroids are thought to be more effective against neurologic toxicities ${ }^{48}$.

\section{PRE-CLINICAL SUCCESS OF CAR-T THERAPY}

Chimeric antigen receptors have been studied widely in clinical and preclinical settings. The toxicities associated with CAR-T-cell application are different in human and animal models. Siegler and Wang (2018) summarized approximately all present preclinical studies performed on mice. The study provided information not only about xenograft, syngeneic, and transgenic models but also about humanized mouse models ${ }^{50}$. A xenotransplant murine model of B-cell malignancy targeting CD19 has also been studied ${ }^{\mathbf{5 1}}$. For some past years, most preclinical studies were performed only on mice. However, there was a need to fill the gap, as there was no such reported neurotoxicity or cytokine release syndrome in murine models. To overcome this, primate models were then used as their immune system matches more closely with humans. However, primate models lack the ability to study antitumor efficacy. [50]. Nevertheless, the use of primate models such as rhesus macaques showed resulting neurotoxicity due to CAR-T application ${ }^{52}$.

\section{CLINICAL SUCCESS OF CAR-T THERAPY}

In 2003, the US led the first CAR-T clinical trial. It was focused on treating epithelial ovarian cancer ${ }^{53}$. This proves the significance of immunotherapy in enhancing the patient survival rate and reducing disease progression ${ }^{54}$. In 2010, Germany and the UK studied CD19-targeted CAR-T therapy in children suffering from ALL. In 2012, the $1^{\text {st }}$ trial using CAR-T cells was performed by the PLAGH group, which focused on studying the effectiveness of CAR-T therapy in refractory lymphomas that are resistant to chemotherapies $^{54}$. In 2013, there was a worldwide increase in the number of conducted trials on CAR-T, and they are still increasing to date ${ }^{53}$. 
Table 1: List of Completed Clinical Trials Retrieved fromClinicaltrials. Gov as per $24^{\text {th }}$ February, 2022

\begin{tabular}{|c|c|c|}
\hline No. & Study Title & Clinical Trial \\
\hline 1 & $\begin{array}{l}\text { Clinical Study of T Cell Infusion Targeting BCMA Chimeric } \\
\text { Antigen Receptor. }\end{array}$ & NCT04650724 \\
\hline 2 & $\begin{array}{l}\text { 4th Generation Chimeric Antigen Receptor T Cells Targeting } \\
\text { Glypican-3 }\end{array}$ & NCT03980288 \\
\hline 3 & $\begin{array}{l}\text { Cell Therapy for CD7 Positive T-cell Acute Lymphoblas- } \\
\text { tic Leukemia and Lymphoblastic Lymphoma Using CD7- } \\
\text { Specific CAR-T Cells }\end{array}$ & NCT04572308 \\
\hline 4 & $\begin{array}{l}\text { Pembrolizumab in Patients Failing to Respond to or Relapsing } \\
\text { After CAR T Cell Therapy for Relapsed or Refractory Lym- } \\
\text { phomas }\end{array}$ & NCT02650999 \\
\hline 5 & $\begin{array}{l}\text { CAR-T Hepatic Artery Infusions and Sir-Spheres for Liver } \\
\text { Metastases }\end{array}$ & NCT02416466 \\
\hline 6 & $\begin{array}{l}\text { CAR T Cell Receptor Immunotherapy Targeting EGFRvIII for } \\
\text { Patients With Malignant Gliomas Expressing EGFRvIII }\end{array}$ & NCT01454596 \\
\hline 7 & $\begin{array}{l}\text { CD19 /22 CAR T Cells (AUTO3) for the Treatment of B Cell } \\
\text { Acute Lymphoblastic Leukemia (ALL) }\end{array}$ & NCT03289455 \\
\hline 8 & $\begin{array}{l}\text { Anti-CD19 Chimeric Antigen Receptor (CAR)-Transduced T } \\
\text { Cell Therapy for Patients With B Cell Malignancies }\end{array}$ & NCT03076437 \\
\hline 9 & Chimeric Antigen Receptor T Cells Targeting Glypican-3 & NCT03884751 \\
\hline 10 & CD19-CAR-T in B-cell Malignancies Patients & NCT03952923 \\
\hline 11 & $\begin{array}{l}\text { CD19 CAR T Cells in Patients With Resistant or Refractory } \\
\text { CD19+ Acute Lymphoblastic Leukemia }\end{array}$ & NCT02975687 \\
\hline 12 & $\begin{array}{l}\text { CD19-targeting, 3rd Generation CAR T Cells for Refractory } \\
\text { B Cells Malignancy }\end{array}$ & NCT03068416 \\
\hline 13 & $\begin{array}{l}\text { A PhaseIb Study Evaluating Safety and Efficacy of C-CAR011 } \\
\text { Treatment in B- NHL Subjects }\end{array}$ & NCT03483688 \\
\hline 14 & $\begin{array}{l}\text { CD19 CAR T Cells in Patients With Relapsed or Refractory } \\
\text { CD19 Positive B-cell Lymphoma }\end{array}$ & NCT03029338 \\
\hline 15 & $\begin{array}{l}\text { Laboratory Treated T Cells in Treating Patients With Relapsed } \\
\text { or Refractory Chronic Lymphocytic Leukemia, Non-Hodgkin } \\
\text { Lymphoma, or Acute Lymphoblastic Leukemia }\end{array}$ & NCT01865617 \\
\hline 16 & $\begin{array}{l}\text { Safety Study of Chimeric Antigen Receptor Modified T-cells } \\
\text { Targeting NKG2D-Ligands }\end{array}$ & NCT02850536 \\
\hline 17 & $\begin{array}{l}\text { CAR-T Hepatic Artery Infusions or Pancreatic Venous Infu- } \\
\text { sions for CEA-Expressing Liver Metastases or Pancreas Can- } \\
\text { cer }\end{array}$ & NCT02203825 \\
\hline 18 & $\begin{array}{l}\text { CD19 CAR T Cells for B Cell Malignancies After Allogeneic } \\
\text { Transplant }\end{array}$ & NCT01475058 \\
\hline 19 & $\begin{array}{l}\text { Treatment of Relapsed and/or Chemotherapy Refractory B- } \\
\text { cell Malignancy by Tandem CAR T Cells Targeting CD19 and } \\
\text { CD20 }\end{array}$ & NCT03811457 \\
\hline 20 & $\begin{array}{l}\text { A Phase I Trial of T Cells Expressing an Anti-GD2 Chimeric } \\
\text { Antigen Receptor in Children and Young Adults With GD2+ } \\
\text { Solid Tumors }\end{array}$ & NCT02107963 \\
\hline 21 & $\begin{array}{l}\text { Immunotherapy With CD19 CAR T-cells in Patients With Re- } \\
\text { lapsed or Refractory CD19+ Leukemia and Lymphoma }\end{array}$ & NCT03097770 \\
\hline 22 & $\begin{array}{l}\text { CAR T Cell Receptor Immunotherapy for Patients With B-cell } \\
\text { Lymphoma }\end{array}$ & NCT03173417 \\
\hline
\end{tabular}




\begin{tabular}{|c|c|c|}
\hline \multicolumn{3}{|c|}{ Table 1 continued } \\
\hline No. & Study Title & Clinical Trial \\
\hline 23 & $\begin{array}{l}\text { Safety and Efficacy Evaluation of IM19 CAR-T Cells } \\
\text { (IM19CAR-T) }\end{array}$ & NCT00924326 \\
\hline 24 & $\begin{array}{l}\text { A Phase } 1 \text { Study Evaluating Safety and Efficacy of C-CAR011 } \\
\text { Treatment in DLBCL Subjects }\end{array}$ & NCT02976857 \\
\hline 25 & $\begin{array}{l}\text { CD19-targeting 3rd Generation CAR T Cells for Refractory B } \\
\text { Cell Malignancy - a Phase I/IIa Trial. }\end{array}$ & NCT02132624 \\
\hline 26 & $\begin{array}{l}\mathrm{T} \text { Cells Expressing a Fully-Human Anti-CD30 Chimeric } \\
\text { Antigen Receptor for Treating CD30-Expressing Lymphomas }\end{array}$ & NCT03049449 \\
\hline 27 & A Phase I Trial of Anti-GD2 T-cells (1RG-CART) & NCT02761915 \\
\hline 28 & $\begin{array}{l}\text { CAR-GPC3 T Cells in Patients With Refractory Hepatocellu- } \\
\text { lar Carcinoma }\end{array}$ & NCT03146234 \\
\hline 29 & $\begin{array}{l}\text { CMV-specific Cytotoxic T Lymphocytes Expressing CAR Tar- } \\
\text { geting HER2 in Patients With GBM }\end{array}$ & NCT01109095 \\
\hline 30 & $\begin{array}{l}\text { Dose Optimization Trial of CD19 Redirected Autologous T } \\
\text { Cells }\end{array}$ & NCT01747486 \\
\hline 31 & $\begin{array}{l}\text { T-cells Expressing an Anti-SLAMF7 CAR for Treating Multi- } \\
\text { ple Myeloma }\end{array}$ & NCT03958656 \\
\hline 32 & $\begin{array}{l}\text { Anti-CD19 White Blood Cells for Children and Young Adults } \\
\text { With B Cell Leukemia or Lymphoma }\end{array}$ & NCT01593696 \\
\hline
\end{tabular}

Table 2: Trial recruitment status with their corresponding details

\begin{tabular}{|c|c|c|}
\hline Recruitment Status & Description & $\begin{array}{l}\text { Clinical Trial } \\
\text { No. }\end{array}$ \\
\hline Not yet recruiting & The study has not started recruiting participants. & 71 \\
\hline Recruiting & The study is currently recruiting participants. & 374 \\
\hline Enrolling by invitation & $\begin{array}{l}\text { The study is selecting its participants from a population, or } \\
\text { group of people, decided on by the researchers in advance. } \\
\text { These studies are not open to everyone who meets the eligi- } \\
\text { bility criteria but only to people in that particular population, } \\
\text { who are specifically invited to participate. }\end{array}$ & 5 \\
\hline Active, not recruiting & $\begin{array}{l}\text { The study is ongoing, and participants are receiving an inter- } \\
\text { vention or being examined, but potential participants are not } \\
\text { currently being recruited or enrolled. }\end{array}$ & 64 \\
\hline Suspended & The study has stopped early but may start again. & 6 \\
\hline Terminated & $\begin{array}{l}\text { The study has stopped early and will not start again. Partici- } \\
\text { pants are no longer being examined or treated. }\end{array}$ & 18 \\
\hline Completed & $\begin{array}{l}\text { The study has ended normally, and participants are no longer } \\
\text { being examined or treated (that is, the last participant's last } \\
\text { visit has occurred). }\end{array}$ & 32 \\
\hline Withdrawn & The study stopped early, before enrolling its first participant. & 12 \\
\hline Unknown status & $\begin{array}{l}\text { A study on ClinicalTrials.gov whose last known status was } \\
\text { recruiting; not yet recruiting; or active, not recruiting but that } \\
\text { has passed its completion date, and the status has not been } \\
\text { last verified within the past } 2 \text { years. }\end{array}$ & 127 \\
\hline
\end{tabular}


Numerous trials have successfully been completed using CAR-T cells to treat various diseases. To analyze the list of total completed trials, we searched ClinicalTrials.gov using the keywords "CAR-T", "CAR-T therapy", and "chimeric antigen receptor" with a filter for "completed" trials. Out of 32 reported trials from clinicaltrials.gov, fourteen were held in different institutions in China and fourteen separately in different regions of the United States. Two were in the United Kingdom, and one was held in Sweden (Table 1). The trials were performed to study the effect of CAR-T cells in curing various conditions, such as ALL, acute myeloid leukemia, relapsed or refractory CLL, B-ALL, brain cancer, FL, glioblastoma multiforme, gliosarcoma, lymphoid cancer, BNHL, MCL, DLBCL, myelodysplastic syndrome, hepatocellular carcinoma, myeloma, neuroblastoma and osteosarcoma.

\section{PRESENT AND FUTURE WORK IN CAR-T THERAPY}

To analyze the list of total trials, the same method was used as employed earlier. We searched overall trials either completed or ongoing by using the keywords "CAR-T," "CAR-T therapy," and "chimeric antigen receptor" on ClinicalTrials.gov. A list of a total of 706 results was obtained for trials that made use of CAR-T therapy in one way or another. The data were further filtered based on recruitment status to obtain more categorized data, as shown in Table 2.

\section{LIMITATIONS OF CAR-T}

One of the limitations of CAR-T therapy is its inapplicability in solid tumors such as pediatric brain tumors, which hinders T-cell transport and proliferation ${ }^{19}$, although it has high enough efficacy for blood cancers ${ }^{28}$. Other limitations include antigenic escape, low persistence, an immunosuppressive microenvironment and other life-threatening conditions following CAR-T-cell infusion ${ }^{55}$. The high cost of the therapy is considered to be another limitation, ranging from 373,000 to 475,000 dollars for CAR-T therapy approved agents by the FDA ${ }^{43}$. Advancement is needed to effectively treat solid tumors and other diseases with minimum toxic effects.

\section{CONCLUSION AND PERSPECTIVE}

For successful application of CAR-T-cell therapy, better toxicity grading and management techniques are required to overcome the toxic side effects and other challenges that hinder effective CAR-T-cell therapy application. The two common and life-threatening
CAR-T therapy-associated toxicities are CRS and neurotoxicity. Getting more knowledge about the underlying causes and mechanism of such toxicities will lead to better management of such toxicity and improved CAR-T efficacy. Additionally, clinical trials and studies to date are focusing more on liquid cancers such as leukemia and lymphomas, and it is urgently needed to expand CAR-T therapy advantages to solid tumors. In short, there is a dire need to perform clinical trials to dig more information so that targeted treatment can be performed with minimum normal cell cytolysis and less toxicity.

\section{ABBREVIATIONS}

ACT: Adoptive T-cell therapy, B-ALL: B-cell acute lymphoblastic leukemia, B-NHL: B-cell non-Hodgkin lymphoma, CAR: Chimeric antigen receptor, CLL: Chronic lymphocytic leukemia, CM: Costimulatory domains, CRS: Cytokine release syndrome, FL: Follicular lymphoma, HL: Hodgkin lymphoma, HLA: Human leukocyte antigen, IL-6: Interlelukin-6, IL-12: Interleukin 12, JAK: Janus kinases, MCL: Mantle cell lymphoma, NK: Natural killer, PLAGH: People's Liberation Army General Hospital, DLBCL: R/R diffuse large B-cell lymphoma, R/R B-ALL: Relapsed or refractory B-ALL, STAT3: Signal transducer and activator of transcription-3, scFv: Single-chain variable fragment, TCR: T-cell receptor, TRUCK: T-cells redirected for universal cytokine mediated killing, WBCs: White blood cells

\section{ACKNOWLEDGMENTS}

The authors are thankful to the Vice-chancellor of the University of the Punjab, Lahore, Pakistan, and the Vice-chancellor of the University of Okara, Punjab, Pakistan, for providing support for the accomplishment of this study. All the figures were drawn using Biorender.com.

\section{AUTHOR'S CONTRIBUTIONS}

MHA, AR, and MBK collected the data, drew the figure, and wrote the manuscript. AF and AM revised the figure and the manuscript. MHA and NS proposed the idea, approved the final draft, and supervised the whole project. All authors read and approved the final manuscript.

\section{FUNDING}

None.

\section{AVAILABILITY OF DATA AND MATERIALS}

Data and materials used and/or analyzed during the current study are available from the corresponding 
author on reasonable request.

\section{ETHICS APPROVAL AND CONSENT TO PARTICIPATE}

Not applicable.

\section{CONSENT FOR PUBLICATION}

Not applicable.

\section{COMPETING INTERESTS}

The authors declare that they have no competing interests.

\section{REFERENCES}

1. Sadelain M, Brentjens R, Rivière I. The basic principles of chimeric antigen receptor design. Cancer Discovery. 2013;3(4):388-98. PMID: 23550147. Available from: 10.1158/ 2159-8290.CD-12-0548.

2. Greinix HT. Role of CAR-T cell therapy in B-cell acute lymphoblastic leukemia. memo-. Magazine of European Medical Oncology. 2020;13(1):36-42. Available from: 10.1007/s12254019-00541-8.

3. Davila ML, Brentjens RJ. CD19-Targeted CAR T cells as novel cancer immunotherapy for relapsed or refractory B-cell acute lymphoblastic leukemia. Clinical advances in hematology \& oncology: H\&O. 2016;14(10):802.

4. Haji-Fatahaliha $M$, Hosseini $M$, Akbarian $A$, Sadreddini $S$ Jadidi-Niaragh F, Yousefi M. CAR-modified T-cell therapy for cancer: an updated review. Artificial Cells, Nanomedicine, and Biotechnology. 2016;44(6):1339-49. PMID: 26068778. Available from: 10.3109/21691401.2015.1052465.

5. Eggermont LJ, Paulis LE, Tel J, Figdor CG. Towards efficient cancer immunotherapy: advances in developing artificial antigen-presenting cells. Trends in Biotechnology. 2014;32(9):456-65. PMID: 24998519. Available from: 10.1016/ j.tibtech.2014.06.007.

6. Miliotou AN, Papadopoulou LC. CAR T-cell therapy: a new era in cancer immunotherapy. Current Pharmaceutical Biotechnology. 2018;19(1):5-18. PMID: 29667553. Available from: $10.2174 / 1389201019666180418095526$

7. Rosenberg SA, Lotze MT, Muul LM, Leitman S, Chang $A E$, Ettinghausen $S E$. Observations on the systemic administration of autologous lymphokine-activated killer cells and recombinant interleukin-2 to patients with metastatic cancer. The New England Journal of Medicine. 1985;313(23):1485-92. PMID: 3903508. Available from: 10.1056/NEJM198512053132327.

8. Gross G, Waks T, Eshhar Z. Expression of immunoglobulinT-cell receptor chimeric molecules as functional receptors with antibody-type specificity. Proceedings of the National Academy of Sciences of the United States of America. 1989;86(24):10024-8. PMID: 2513569. Available from: 10.1073/pnas.86.24.10024.

9. Sadelain $M$, Brentjens $R$, Rivière $I$. The basic principles of chimeric antigen receptor design. Cancer Discovery. 2013;3(4):388-98. PMID: 23550147. Available from: 10.1158/ 2159-8290.CD-12-0548.

10. Srivastava S, Riddell SR. Engineering CAR-T cells: design concepts. Trends in Immunology. 2015;36(8):494-502. PMID: 26169254. Available from: 10.1016/j.it.2015.06.004.

11. Park JH, Brentjens RJ. Adoptive immunotherapy for Bcell malignancies with autologous chimeric antigen receptor modified tumor targeted T cells. Discovery Medicine. 2010;9(47):277-88. PMID: 20423671.

12. Park JH, Geyer MB, Brentjens RJ. CD19-targeted CAR T-cell therapeutics for hematologic malignancies: interpreting clinical outcomes to date. Blood. 2016;127(26):3312-20. PMID:
27207800. Available from: 10.1182/blood-2016-02-629063.

13. Feins S, Kong W, Williams EF, Milone MC, Fraietta JA. An introduction to chimeric antigen receptor (CAR) T-cell immunotherapy for human cancer. American Journal of Hematology. 2019;94:3-9. PMID: 30680780. Available from: 10. 1002/ajh.25418.

14. Srivastava S, Riddell SR. Engineering CAR-T cells: design concepts. Trends in Immunology. 2015;36(8):494-502. PMID: 26169254. Available from: 10.1016/j.it.2015.06.004.

15. Park JH, Brentjens RJ. Adoptive immunotherapy for Bcell malignancies with autologous chimeric antigen receptor modified tumor targeted T cells. Discovery Medicine. 2010;9(47):277-88. PMID: 20423671.

16. Park JH, Rivière I, Gonen $M$, Wang $X$, Sénéchal $B$, Curran KJ. Long-term follow-up of CD19 CAR therapy in acute lymphoblastic leukemia. The New England Journal of Medicine. 2018;378(5):449-59. PMID: 29385376. Available from: 10. 1056/NEJMoa1709919.

17. Abate-Daga D, Davila ML. CAR models: next-generation CAR modifications for enhanced T-cell function. Molecular Therapy Oncolytics. 2016;3:16014. PMID: 27231717. Available from: $10.1038 / \mathrm{mto} .2016 .14$

18. Sadelain M, Rivière I, Brentjens R. Targeting tumours with genetically enhanced T lymphocytes. Nature Reviews Cancer. 2003;3(1):35-45. PMID: 12509765. Available from: 10.1038/ nrc971.

19. Wu WT, Lin WY, Chen YW, Lin CF, Wang HH, Wu SH. New Era of Immunotherapy in Pediatric Brain Tumors: Chimeric Antigen Receptor T-Cell Therapy. International Journal of Molecular Sciences. 2021;22(5):2404. PMID: 33673696. Available from: $10.3390 / \mathrm{ijms} 22052404$

20. Zhang C, Liu J, Zhong JF, Zhang X. Engineering CAR-T cells. Biomarker Research. 2017;5(1):22. PMID: 28652918. Available from: 10.1186/s40364-017-0102-y.

21. Firor $A E$, Jares $A, M a Y$. From humble beginnings to success in the clinic: chimeric antigen receptor-modified T-cells and implications for immunotherapy. Experimental Biology and Medicine (Maywood, NJ). 2015;240(8):1087-98. PMID: 25956686. Available from: $10.1177 / 1535370215584936$.

22. Imai C, Mihara K, Andreansky M, Nicholson IC, Pui CH, Geiger TL. Chimeric receptors with 4-1BB signaling capacity provoke potent cytotoxicity against acute lymphoblastic leukemia. Leukemia. 2004;18(4):676-84. PMID: 14961035. Available from: 10.1038/sj.leu.2403302.

23. Brentjens RJ, Santos E, Nikhamin Y, Yeh R, Matsushita M, Perle $\mathrm{KL}$. Genetically targeted T cells eradicate systemic acute lymphoblastic leukemia xenografts. Clinical Cancer Research. 2007;13(18 Pt 1):5426-35. PMID: 17855649. Available from: 10.1158/1078-0432.CCR-07-0674.

24. Finney HM, Lawson AD, Bebbington CR, Weir AN. Chimeric receptors providing both primary and costimulatory signaling in T cells from a single gene product. Journal of Immunology (Baltimore, Md: 1950). 1998;161(6):2791-7. PMID: 9743337.

25. Heczey A, Louis CU, Savoldo B, Dakhova O, Durett A, Grilley B. CAR T cells administered in combination with lymphodepletion and PD-1 inhibition to patients with neuroblastoma. Molecular Therapy. 2017;25(9):2214-24. PMID: 28602436. Available from: 10.1016/j.ymthe.2017.05.012.

26. Morgan RA, Yang JC, Kitano M, Dudley ME, Laurencot CM Rosenberg SA. Case report of a serious adverse event following the administration of T cells transduced with a chimeric antigen receptor recognizing ERBB2. Molecular Therapy. 2010;18(4):843-51. PMID: 20179677. Available from: 10.1038/ $\mathrm{mt} .2010 .24$.

27. Chmielewski M, Abken H. TRUCKs: the fourth generation of CARs. Expert Opinion on Biological Therapy. 2015;15(8):114554. PMID: 25985798. Available from: 10.1517/14712598.2015. 1046430.

28. Tokarew N, Ogonek J, Endres S, von Bergwelt-Baildon M, Kobold S. Teaching an old dog new tricks: next-generation CAR T cells. British Journal of Cancer. 2019;120(1):26-37. 
PMID: 30413825. Available from: 10.1038/s41416-018-0325-1.

29. Kagoya Y, Tanaka S, Guo T, Anczurowski M, Wang CH, Saso K A novel chimeric antigen receptor containing a JAK-STAT signaling domain mediates superior antitumor effects. Nature Medicine. 2018;24(3):352-9. PMID: 29400710. Available from: $10.1038 / \mathrm{nm} .4478$.

30. Cordes $N$, Kolbe $C$, Lock $D$, Holzer $T$, Althoff $D$, Schäfer $D$, et al. Anti-CD19 CARs displayed at the surface of lentiviral vector particles promote transduction of target-expressing cells. Molecular Therapy Methods \& Clinical Development. 2021;21:42-53. PMID: 33768128. Available from: $10.1016 / j$. omtm.2021.02.013.

31. Wall DA, Krueger J. Chimeric antigen receptor $T$ cell therapy comes to clinical practice. Current Oncology (Toronto, Ont). 2020;27(12):115-23. PMID: 32368181. Available from: $10.3747 /$ co.27.5283.

32. Priceman SJ, Forman SJ, Brown CE. Smart CARs engineered for cancer immunotherapy. Current Opinion in Oncology. 2015;27(6):466-74. PMID: 26352543. Available from: 10.1097/ CCO.0000000000000232.

33. Maude SL, Laetsch TW, Buechner J, Rives S, Boyer M, Bittencourt $\mathrm{H}$. Tisagenlecleucel in children and young adults with B-cell lymphoblastic leukemia. The New England Journal of Medicine. 2018;378(5):439-48. PMID: 29385370. Available from: 10.1056/NEJMoa1709866.

34. Neelapu SS, Locke FL, Bartlett NL, Lekakis LJ, Miklos DB, Jacobson CA. Axicabtagene ciloleucel CAR T-cell therapy in refractory large B-cell lymphoma. The New England Journal of Medicine. 2017;377(26):2531-44. PMID: 29226797. Available from: 10.1056/NEJMoa1707447.

35. Turtle CJ, Hanafi LA, Berger C, Gooley TA, Cherian S, Hudecek M. CD19 CAR-T cells of defined CD4+:CD8+ composition in adult $B$ cell ALL patients. The Journal of Clinical Investigation. 2016;126(6):2123-38. PMID: 27111235. Available from: 10. 1172/JCI85309.

36. Turtle CJ, et al. Immunotherapy of non-Hodgkin's lymphoma with a defined ratio of CD8+ and CD4+ CD19-specific chimeric antigen receptor-modified $T$ cells. Science translational medicine. 2016;8(355):355ra116-355ra116. Available from: 10.1126/scitranslmed.aaf8621.

37. Grupp SA. Durable remissions in children with relapsed/refractory all treated with t cells engineered with a CD19-targeted chimeric antigen receptor (CTL019). DC: American Society of Hematology Washington; 2015. Available from: 10.1182/blood.V126.23.681.681.

38. Kochenderfer JN, Dudley ME, Kassim SH, Somerville RP, Carpenter RO, Stetler-Stevenson M. Chemotherapy-refractory diffuse large B-cell lymphoma and indolent B-cell malignancies can be effectively treated with autologous $T$ cells expressing an anti-CD19 chimeric antigen receptor. Journal of Clinical Oncology. 2015;33(6):540-9. PMID: 25154820. Available from: 10.1200/JCO.2014.56.2025.

39. Singh N, Frey NV, Grupp SA, Maude SL. CAR T cell therapy in acute lymphoblastic leukemia and potential for chronic lymphocytic leukemia. Current Treatment Options in Oncology. 2016;17(6):28. PMID: 27098534. Available from: 10.1007/ s11864-016-0406-4.

40. Johnson LA, June $\mathrm{CH}$. Driving gene-engineered T cell immunotherapy of cancer. Cell Research. 2017;27(1):38-58. PMID: 28025979. Available from: 10.1038/cr.2016.154.

41. Zhang WY, Wang Y, Guo YL, Dai HR, Yang QM, Zhang YJ. Treatment of CD20-directed Chimeric Antigen Receptor-modified $\mathrm{T}$ cells in patients with relapsed or refractory B-cell nonHodgkin lymphoma: an early phase lla trial report. Signal
Transduction and Targeted Therapy. 2016;1(1):16002. PMID: 29263894. Available from: 10.1038/sigtrans.2016.2.

42. Wang CM, Wu ZQ, Wang Y, Guo YL, Dai HR, Wang XH. Autologous $T$ cells expressing CD30 chimeric antigen receptors for relapsed or refractory Hodgkin lymphoma: an open-label phase I trial. Clinical Cancer Research. 2017;23(5):1156-66. PMID: 27582488. Available from: 10.1158/1078-0432.CCR-161365.

43. Prasad V. Immunotherapy: Tisagenlecleucel - the first approved CAR-T-cell therapy: implications for payers and policy makers. Nature Reviews Clinical Oncology. 2018;15(1):11-2. PMID: 28975930. Available from: 10.1038/nrclinonc.2017.156.

44. Ahmad A, Uddin S, Steinhoff M. Car-t cell therapies: an overview of clinical studies supporting their approved use against acute lymphoblastic leukemia and large b-cell lymphomas. International Journal of Molecular Sciences. 2020;21(11):3906. PMID: 32486160. Available from: 10.3390/ ijms21113906.

45. Yip A, Webster RM. The market for chimeric antigen receptor T cell therapies. Nature Reviews Drug Discovery. 2018;17(3):161-2. PMID: 29375140. Available from: 10.1038/ nrd.2017.266

46. Mullard A. FDA approves first BCMA-targeted CAR-T cell therapy. Nature reviews. Drug Discovery, 2021.

47. Munshi NC, Anderson LD, Shah N, Madduri D, Berdeja J, Lonial S. Idecabtagene vicleucel in relapsed and refractory multiple myeloma. The New England Journal of Medicine. 2021;384(8):705-16. PMID: 33626253. Available from: 10. 1056/NEJMoa2024850.

48. Brudno JN, Kochenderfer JN. Recent advances in CAR Tcell toxicity: Mechanisms, manifestations and management. Blood Reviews. 2019;34:45-55. PMID: 30528964. Available from: 10.1016/j.blre.2018.11.002.

49. Si S, Teachey DT. Spotlight on Tocilizumab in the Treatment of CAR-T-Cell-Induced Cytokine Release Syndrome: Clinical Evidence to Date. Therapeutics and Clinical Risk Management. 2020;16:705-14. PMID: 32801727.

50. Siegler EL, Wang P. Preclinical Models in Chimeric Antigen Receptor-Engineered T-Cell Therapy. Human Gene Therapy. 2018;29(5):534-46. PMID: 29390873. Available from: 10.1089/ hum.2017.243.

51. Lee JC, Hayman E, Pegram HJ, Santos E, Heller G, Sadelain M. In vivo inhibition of human CD19-targeted effector T cells by natural $T$ regulatory cells in a xenotransplant murine model of B cell malignancy. Cancer Research. 2011;71(8):2871-81. PMID: 21487038. Available from: 10.1158/0008-5472.CAN10-0552.

52. Taraseviciute A, Tkachev V, Ponce R, Turtle CJ, Snyder JM, Liggitt HD. Chimeric Antigen Receptor T Cell-Mediated Neurotoxicity in Nonhuman Primates. Cancer Discovery. 2018;8(6):750-63. PMID: 29563103. Available from: 10.1158/ 2159-8290.CD-17-1368.

53. Wei J, Guo $Y$, Wang $Y$, Wu Z, Bo J, Zhang B, et al. Clinical development of CAR T cell therapy in China: 2020 update. Cellular \& Molecular Immunology. 2021;18(4):792-804. PMID: 32999455. Available from: 10.1038/s41423-020-00555-x.

54. Zhang L, Conejo-Garcia JR, Katsaros D, Gimotty PA, Massobrio $\mathrm{M}$, Regnani $\mathrm{G}$. Intratumoral T cells, recurrence, and survival in epithelial ovarian cancer. The New England Journal of Medicine. 2003;348(3):203-13. PMID: 12529460. Available from: 10.1056/NEJMoa020177.

55. Sterner RC, Sterner RM. CAR-T cell therapy: current limitations and potential strategies. Blood Cancer Journal. 2021;11(4):69. PMID: 33824268. Available from: 10.1038/s41408-021-00459- 
Ready to submit your manuscript? Choose Biomedpress and benefit from:

- Fast, convenient online submission

- Through peer-review by experienced researchers

- Rapid publication on acceptance

- Free of charge (without publication fees)

Learn more http://www.biomedpress.org/journals/
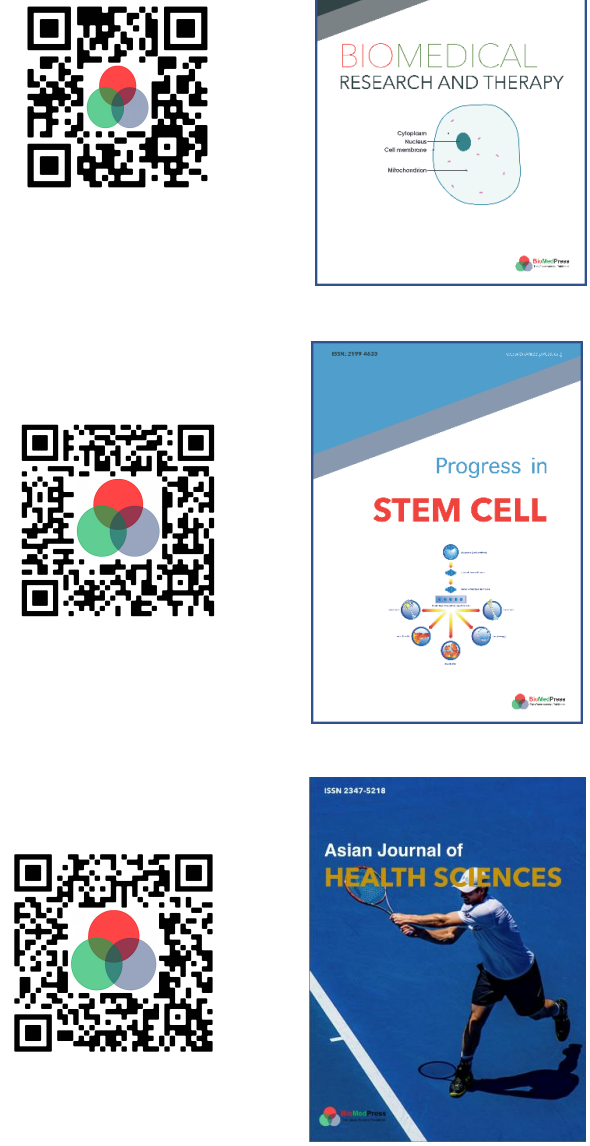

Asian Journal of Health Sciences

ISSN: 2347-5218

Indexed: Google Scholar

Acceptance Rate (2020): 72.89\%

Article Publishing Charge: Free

Submission to first editorial decision: 16.5 days

Biotechnological Research

ISSN: 2395-6763

Indexed: Google Scholar

Acceptance Rate (2020): $67.02 \%$

Article Publishing Charge: Free

Submission to first editorial decision: 28.5 days 